Volume 3 Nomor 1, Maret 2021, Halaman 1-16

\title{
SOSIALISASI PEMANFATAAN APLIKASI MEDIA SOSIAL DALAM PEMBELAJARAN DARING SELAMA PANDEMI COVID-19 PADA TK AL-ZHARUFA KOTA CIMAHI
}

\author{
Deni Hadiansah 1), Desty Rara Pringgandinie 2), Agus Winarti ${ }^{3)}$, \\ Livia Astuti 4), Fajar Setyaning Dwi Putra 5), Anne Rahaju 6) \\ 1, 2, 3, 4. 5, 6 Universitas Insan Cendekia Mandiri Bandung \\ Email: denihadiansah@gmail.com ${ }^{1}$, destyrara@gmail.com ${ }^{2}$, \\ aguswinarti56@gmail.com ${ }^{3}$, iviastuti.fkip@gmail.com ${ }^{4}$, \\ fajarsetyaningdwiputra@gmail.com ${ }^{5}$, nne.adinda@gmail.com ${ }^{6}$.
}

\begin{abstract}
Abstrak
Sejak pandemi Covid-19 melanda, TK Al-Zharufa melaksanakan pembelajaran daring. Atas kebijakan tersebut, muncul beberapa kendala dan masalah dalam pelaksanaannya. Tujuan kegiatan pengabdian ini adalah sosialisasi pemanfaatan aplikasi media sosial dalam pembelajaran daring pada TK Al-Zharufa sebagai salah satu upaya mengatasi kendala yang dialami. Kegiatan pengabdian dilaksanakan dengan metode penyuluhan melalui teknik presentasi virtual melalui aplikasi Zoom Meeting. Selain itu, digunakan teknik wawancara untuk mengetahui kebutuhan topik materi sosialisasi. Tahapan kegiatan meliputi perencanaan, pengkoordinasian, pelaksanana, dan evaluasi. Simpulan dari hasil kegiatan pengabdian bahwa, (1) Kegiatan sosialisasi daring berjalan lancar; dan (2) Kegiatan sosialisasi cukup membantu pengelola dan guru-guru TK Al-Zharufa dalam mengembangkan wawasan baik secara teoretis maupun praktis tentang pemanfaatan aplikasi media sosial dalam pembelajaran daring selama pandemi Covid-19. Demikian, kegiatan sejenis perlu dilaksanakan secara berkala dan berkelanjutan..
\end{abstract}

Kata Kunci : TK Al-Zharufa, Aplikasi Media Sosial, Pembelajaran Daring

\begin{abstract}
Since the Covid-19 pandemic hit, Al-Zharufa Kindergarten has carried out online learning. Due to this policy, several obstacles and problems emerged in its implementation. The purpose of this service activity is to socialize the use of social media applications in online learning at Al-Zharufa Kindergarten as an effort to overcome the obstacles experienced. Community service activities are carried out by extension methods through virtual presentation techniques through the Zoom Meeting application. In addition, interview techniques are used to determine the need for the topic of socialization material. The activity stages include planning, coordinating, implementing, and evaluating. The conclusion from the results of community service activities is that, (1) Online socialization activities are running smoothly; and (2) The socialization activities are sufficient to assist the managers and teachers of Al-Zharufa Kindergarten in developing both theoretical and practical insights regarding the use of social media applications in online learning
\end{abstract}


during the Covid-19 pandemic. Thus, similar activities need to be carried out periodically and continuously.

Keywords: Al-Zharufa Kindergarten, Social Media Applications, Online Learning

DOI: https://doi.org/10.31943/abdi.v3i1.33

\section{A. Pendahuluan}

Pada tanggal 11 Maret 2020, Covid-19 resmi ditetapkan sebagai pandemi. Pada bidang pendidikan, pemerintah pun mengeluarkan Surat Edaran Mendikbud No. 4 tahun 2020 yang isisnya menetapkan ketentuan belajar dari rumah (learn from home), termasuk pada lingkungan Pendidikan Anak Usia Dini (Hasbi, Wardhani, Widiyawati, 2020:iv). Kondisi tidak tertuga tersebut, tentu saja menggemparkan seluruh pemangku pendidikan di Indonesia, termasuk guru, orang tua, dan siswa. Menurut Ayuni (2020:414) pandemi Covid-19 memberikan dampak pada berbagai aspek kehidupan, salah satunya bidang pendidikan yang mengaharuskan pembelajaran daring.

Berkaitan dengan Pendidikan Anak Usia Dini (PAUD), kondisi tersebut menjadi problematika tersendiri. Oleh karena itu, guru dan orang tua harus memiliki kesiapan dan keterampilan khusus. Selain itu, guru pun harus memiliki kepercayaan diri (Maiza \& Nurhafizah, 2019; Zubaidi, 2020).

Pentingnya keberlangsungan proses pembelajaran pada jenjang PAUD, memang sejalan dengan pendapat Mansur (2011:1) bahwa kelompok anak usia dini tengah berada dalam proses pertumbuhan dan perkembangan unik. Pada kelompok tersebut, anak perlu dikembangkan lebih optimal baik motoriknya, daya pikir, daya cipta, maupun bahasa dan komunikasi sesuai dengan tingkat pertumbuhan dan perkembangannya. Oleh karena itu, perlu diarahkan dan dipetakan secara tepat da optimal. Berkaitan dengan hal itu, Semiawan (2007:19) menyatakan bahwa proses pembelajaran pada anak usia dini harus bermakna, berbasis pada pengalaman nyata (faktual) dan membangkitkan aktivitas serta rasa ingin tahu (curiousity) anak-anak secara optimal.

Jika menilik secara konseptual, pentingnya PAUD ditegaskan dalam Permendikbud No. 84 Tahun 2014 tentang Pendirian Satuan Pendidikan Anak Usia 
Dini. Pada peraturan tersebut, dijelaskan bahwa PADU merupakan suatu upaya pembinaan yang ditujukan kepada anak 0-6 tahun yang dilakukan melalui pemberian rangsangan pendidikan untuk membantu pertumbuhan dan perkembangan jasmani dan rohani agar anak memiliki kesiapan dalam memasuki pendidikan lebih lanjut. Adapun salah satu bentuk satuan PAUD yang bersifat formal dikenal dengan sebutan Taman Kanak-Kanak (TK). Pada jenjang ini, diselenggarakan program pendidikan bagi anak berusia 4-5 tahun dan 5-6 tahun.

Peraturan di atas, sejalan pula dengan Undang-Undang No. 20 Tahun 2003 tentang Sistem Pendidikan Nasional, Bab I, Pasas 1 Ayat 14 bahwa PAUD adalah suatu upaya pembinaan yang ditujukan kepada anak sejak lahir (0 tahun) sampai 6 tahun yang dilakukan melalui pemberian rangsangan pendidikan untuk membentu pertumbuhan dan perkembangan jasmani dan rohani agar anak memiliki kesiapan dalam memasuki pendidikan lebih lanjut.

Merujuk pada peraturan tersebut, jelas bahwa anak-anak yang berada pada usia 0-6 tahun masuk kategori PAUD. Batasan umur ini bermakna bahwa anakanak tersebut belum menginjak pendidikan wajib di SD (Sekolah Dasar). Meskipun Bredekamp dan Copple (1997) menyatakan bahwa anak usia dini itu antara 0-8 tahun. Pendapat tersebut, sejalan pula dengan organisasi profesional untuk pendidikan anak usia dini (National Association for the Education of Young Children/NAEYC) yang memasukan rentang anak usia dini dari 0 sampai 8 tahun. Hanya saja, dalam sistem pendidikan di Indonesia, usia 8 tahun sudah memasuki jenjang SD. Oleh karena itu, pendidikan anak usia dini dalam kajian ini posisinya pada rentang 0-6 tahun.

Pada Kurikulum PAUD, lingkup perkembangan anak usia dini meliputi berbagai aspek, yaitu: perkembangan motorik, kognitif, emosi, sosial, bahasa, moral dan agama. Kelima aspek tersebut integral saling kelindan sebagaimana terlihat pada gambar berikut: 


\section{ABDI WIRALODRA

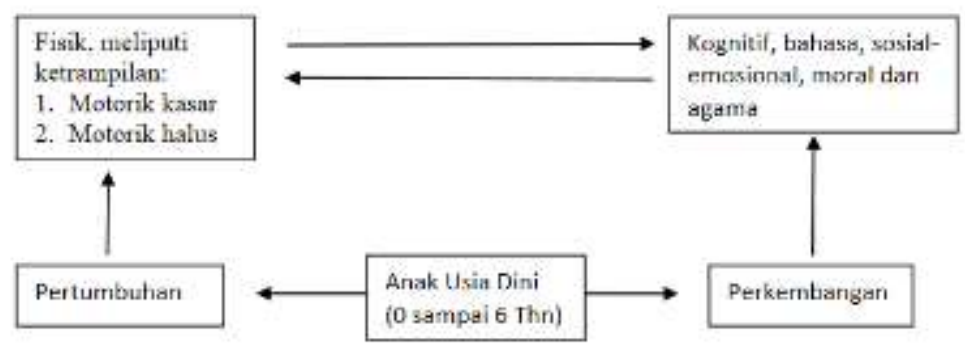

Gambar 1. Ruang Lingkup Psikologi Perkembangan Anak Usia Dini

Sumber: Wiyani (201:10).

Berdasarkan Gambar 1., dapat dilihat bahwa pembelajaran bagi anak TK bukanlah hal yang ringan. Oleh karena itu, ketika kondisi pandemi Covid-19 terjadi, maka mengubah pula kondisi pembelajaran pada PAUD, termasuk pada bentuk Taman Kanak-Kanak (TK). Berdasarkan catatan Kemendikbud (2020) banyak kendala yang dialami guru dan orang tua berkaitan dengan kegiatan pembelajaran dai rumah pada jenjang PAUD. Oleh karena itu, pemerintah pun melalui Direktorat Pendidikan Anak Usia Dini telah menyusun beberapa perangkat bahan ajar sebagai pendukung kegiatan belajara daring. Secara teknis, bahan ajar ini bertujuan agar orang tua dan guru dapat berkolaborasi melayani anak dalam kegiatan pembelajaran di rumah.

Kemudian bisa dijelaskan bahwa pada dasarnya kebijakan Belajar Dari Rumah (BDR) berlaku bagi semua jenjang pendidikan baik dari tingkat TK hingga PT. Kebijakan tersebut merupakan langkah strategis sekaligus inisiatif dari pemerintah dalam menghadapi pandemi Covid-19. Kegiatan pembelajaran dilaksanakan jarak jauh, tanpa tatap muka, dan tidak dibatasi ruang dan waktu dengan berbagai aplikasi media sosial. Adiwijaya (2020) menyebutnya sebagai pembelajaran daring. Secara teknis memang seperti sederhana, guru dan siswa belajar dan mengajar di rumah. Pada makna lain bahwa kegiatan pembelajaran harus terbebas dari kerumunan atau menjaga jarak. Tujuannya demi menghambat penularan atau penyebaran Covid-19 secara masif pada anak-anak sekolah. Menurut Oktaria dan Putra (2020:45) dipercaya akan memperkecil peluang 
penyebaran pada anak-anak yang masuk kategori rentan. Hanya saja, kenyataan proses pembelajaran daring di lapangan menemui berbagai kendala.

Pandemi Covid-19 memang telah menyebabkan perubahan tatanan pendidikan. Salah satunya melalui "Belajar dari Rumah" (Kemendikbud, 2020). Rumah yang tadinya tempat santai dan kumpul keluarga, kini menjadi tempat formal untuk belajar. Kegiatan pembelajaran pun dilaksanakan jarak jauh (Zamzami, 2021:987). Memang secara konseptual, menurut Runisah et al. (2019) pengembangan perangkat lunak dalam sistem pembelajaran bermakna sangat diwarnai model-model pembelajaran berbasis IT. Dengan demikian, jelas bahwa pembelajaran daring secara otomatis akan diwarnai pengembangan perangkat lunak ataupun berbagai aplikasi pembelajaran agar sesuai dengan situasi dan kondisi, termasuk kemampuan guru dan siswa. Akhirnya beberapa satuan PAUD berusaha memfasilitasi siswa dan guru-gurunya memakai aplikasi teknologi komunikasi, hanya saja bagi satuan PAUD lain langkah ini kesulitan. Rendahnya kemampuan guru dan ketersediaan fasilitas menjadi alasan utama, termasuk pada TK Al-Zharufa Cimahi.

Kehadiran kegiatan pembelajaran daring di masa pandemi Covid-19 pada jenjang TK, akhirnya menimbulkan banyak problematika. Menurut catatan Kemendikbud (2020) bahwa hanya sebagian satuan PAUD yang menjalankan kegiatan pembelajaran dnegan memanfaatkan teknologi komunikasi secara optimal. Sebagian mengalami kesulitan akibat lemah atau tidak tersedianya jaringan internet. Berbagai usaha dan strategi pun dilaksanakan oleh pemerintah pusat dan daerah, yaitu melalui penyediaan bahan ajar dan konten-konten pembelajaran secara daring. Beberapa aplikasi disediakan, pemenuhan kuota bagi guru dan siswa, juga penayangan acara pendidikan di TVRI. Pada jenjang TK tidak ketinggalan, kehadiran Rumah Belajar, PAUD Pedia dan Anggun PAUD cukup membantu pengelola satuan pendidikan.

Memang dengan kondisi pandemi, Pembelajaran Jarak jauh (PJJ) akhirnya menjadi opsi paling aman untuk memutus penularan virus Covid-19, khususnya pada anak TK dan PAUD. Meskipun kenyatannya, pembelajaran daring menuai 
pro-kontra di masyarakat. Beberapa pihak bahkan tidak setuju konsep PJJ diterapkan pada anak PAUD dan TK, alasannya dapat menimbulkan stres. Menyikapi hal tersebut, pemerintah tetap pada pendiriannya bahwa pembelajaran daring pada PAUD dan TK justru perlu dilakukan. Hanya saja tinggal pembimbingan yang optimal demi menjaga tumbuh kembang anak dengan menjaga ritme belajar anak harus menggembirakan dan menyenangkan. Pada titik ini, kolaborasi menjadi hal penting antara orang tua, guru, dan pihak sekolah (https://mediaindonesia.com).

Beberapa kendala atau masalah di atas, tentu saja harus menjadi perhatian. Pendidikan anak usia dini harus mendapat pelayanan prima, sebab mereka berada pada tahapan emas (Suhendro, 2020). Hal ini sangat penting, sebab secara teoretis masa emas (golden age) hanya dialami sekali dalam periode kehidupan manusia. Periode emas ini menurut Suhendro dan Syaefudin (2020:3) tidak dapat diulang dalam kehidupan anak.

Berkaitan dengan masalah pembelajaran daring, dirasakan pula oleh pengelola TK Al-Zharufa Kota Cimahi. Menurut wawancara pendahuluan, beberapa masalah yang dihadapi, antara lain: (1) sekolah belum memiliki Learning Management System (LMS) yang standar, sehingga kegiatan pembelajaran daring hanya menggunakan aplikasi yang telah tersedia, (2) Guru-guru dan pengelola sekolah/yayasan, masih kaget dan gagap atas kondisi yang terjadi, sehingga terkesan kegiatan masih trial and error, untuk mencari cara yang terbaik, dan (3) Tidak semua orang tua siswa siap dengan kondisi pembelajaran daring, termasuk kemampuan dalam penggunaan aplikasi atau perangkat internet.

Berdasarkan masalah yang dihadapi oleh pengelola TK Al-Zharufa tersebut, maka Tim Pengabdian Kepada Masyarakat (PKM) FKIP Universitas Bandung Raya sepakat untuk mengadakan kerjasama dalam bentuk penyuluhan. Adapun kegiatannya berupa sosialisasi ihwal pemanfataan aplikasi media sosial dalam pembelajaran daring di TK. Harapannya, pengelola dan guru-guru di TK AlZharufa semakin luas wawasannya berkaitan dengan aplikasi media sosial yang dapat digunakan dalam pembelajaran daring. Pertimbangan dipilihnya TK Al- 
Zharufa karena berdasarkan wawancara pendahuluan, pengelola membutuhkan sosialisasi atau kegiatan sejenis tentang pelaksanaan pembelajaran daring. Selain itu, profil TK secara umum telah tercatat pada sistem daring https://manajemen.paud-dikmas.kemdikbud.go.id/. Adapun tulisan ini, merupakan intisari laporan dari kegiatan yang telah dilaksanakan.

\section{B. Metode}

Kegiatan sosialisasi pemanfaatan aplikasi media sosial dalam pembelajaran daring di TK Al-Zharufa ini menggunakan metode penyuluhan. Secara umum, penyuluhan merupaka suatau upaya atau cara menyampaikan pesan atau informasi kepada yang membutuhkan. Dalam persepktif ilmu sosial, menurut Setiana (2005) penyuluhan dapat dimaknai pendidikan untuk orang dewasa agar terjadi proses perubahan yang lebih baik pada individu serta masyarakat sesuai harapan. Ban dan Hawkins (1999) menyatakan bahwa dalam penyuluhan melibatkan seseorang dalam melakukan komunikasi informasi untuk memberikan pendapat agar menghasilkan keputusan yang benar.

Tahapan kegiatan sosialisasi, meliputi: (1) perencanaan, (2) pengorganisasian, (3) pelaksanaan, dan (4) evaluasi. Pada tahapan perencanaan, dilaksanakan wawancara pendahuluan untuk mengetahui dan menyepakati materi serta teknik pelaksanaan. Pada tahap perencanana, disusun materi dan jadwal sosialisasi. Pada tahap pelaksanaan, digunakan teknik presentasi virtual melalui aplikasi Zoom Meeting. Selain itu, digunakan teknik wawancara untuk mengetahui kebutuhan dan menyepakati topik sosialisasi. Peserta sosialisasi adalah guru dan pengelola TK AlZharufa, berlamat di Kav. Bukit Sangkuriang Blok A No. 2, Cipageran, Kec. Cimahi Utara, Kota Cimahi Prov. Jawa Barat yang dilaksanakan pada hari Senin, 14 September 2020. Adapun evaluasi kegiatan dilaksanakan secara daring, praktiknya seluruh peserta mengisi borang GoogleForm yang isinya penilaian umum terhadap pelaksanaan kegiatan. Penggunaan borang GoogleForm karena lebih mudah dipahami dan digunakan oleh peserta kegiatan. 


\section{ABDI WIRALODRA}

JURNAL PENGABDIAN KEPADA MASYARAKAT
ISSN 2656-5501 (Print)

ISSN 2714-8041 (Online)

\section{Hasil dan Pembahasan}

\section{Profil TK Al-Zharufa Kota Cimahi}

Meskipun penyuluhan dilaksanakan daring, secara sekilas perlu disampikan tentang TK yang guru-gurunya dijadikan sasaran atau objek pelatihan. TK AlZharufa beralamat di Kav. Bukit Sangkuriang Blok A No. 2 , Cipageran, Kec. Cimahi Utara, Kota Cimahi Prov. Jawa Barat. Berdasarkan pemetaan pada goole map, lokasi TK Al-Zharufa dapat dilihat sebagai berikut.

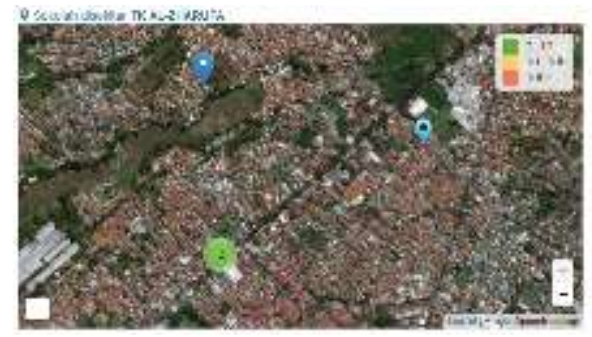

Gambar 2. Peta Lokasi TK Al-Zharufa Kota Cimahi

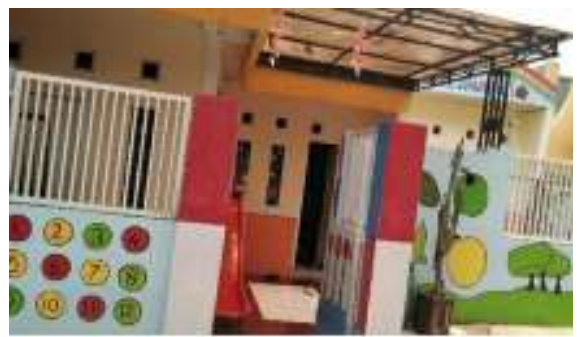

Gambar 3. Bangunan Tampak Depan TK Al-Zharufa Kota Cimahi

Berdasarkan hasil wawancara melalui telepon dengan Kepala Sekolah TK Al-Zharufa, Tuti Herawati, dijelaskan bahwa TK Al-Zharufa telah terakreditasi B. TK Al-Zharufa berdiri sejak tahun 2005, berdasarkan SK Pendirian No. C1730.HT.01.02.TH 2005. Adapun izin operasional baru keluar pada tahun 2017, melalui SK Izin Operasional No. 421.9/Kep.2820-DISDIK/2017.

Selanjutnya, data Pendidik dan Tenaga Kependidikan (PTK) di TK AlZharufa berjumlah orang. Hanya saja, kegiatan pelatihan diikuti oleh 9 orang, ditambah dengan pengelola Yayasan. Jumlah siswa 17 orang dengan rincian lakilaki 10 orang dan perempuan 7 orang.

Berdasarkan data yang diperoleh dari pihak sekolah, hingga tahun 2020, TK Al-Zharufa memiliki kesiapan dalam kegiatan dan media komunikasi, informasi dan edukasi (KIE) tentang sanitasi sekolah. Hal ini sesuai dengan variabel isian yang dikeluarkan dalam laman Dapodik Kemendikbud (2020). Kondisi ini berkesesuaian dengan kondisi fasilitas lainnya yang telah memenuhi standar, sebagaimana dapat dilihat pada gambar berikut. 


\section{ABDI WIRALODRA}

JURNAL PENGABDIAN KEPADA MASYARAKAT
ISSN 2656-5501 (Print)

ISSN 2714-8041 (Online)
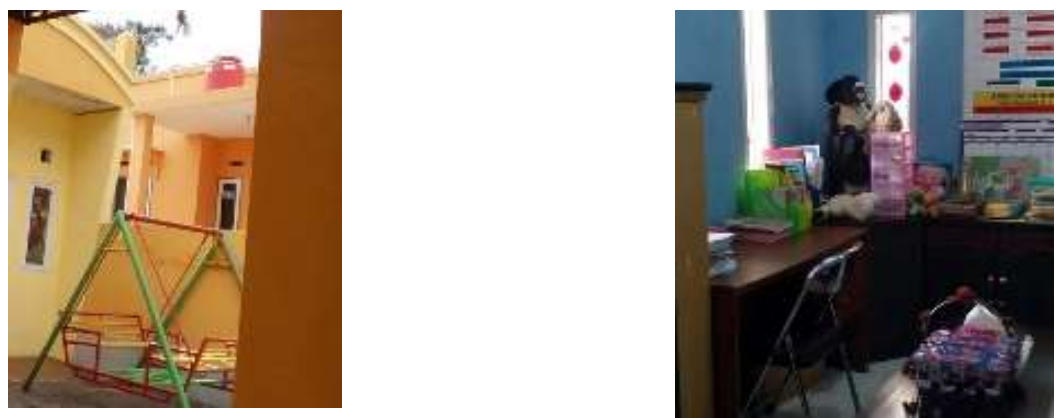

Gambar 4. Situasi dan Kondisi TK Al- Gambar 5. Situasi dan Kondisi TK AlZharufa Tampak Luar

Zharufa Tampak Dalam

Pada gambar 4 dan gambar 5 merupakan akibat pandemi Covid-19, TK AlZharufa tidak menggelar pebelajaran tatap muka. Oleh karena itu, ketika Tim PKM menyambangi lokasi, tampak sepi tidak ada aktivitas seperti biasa.

\section{Tahap Perencanaan dan Pengorganisasian Kegiatan Sosialisasi}

Pembelajaran secara daring secara umum dilakukan dengan menggunakan berbagai platform atau aplikasi. Selain itu, digunakan pula media sebagai penunjang kegiatan belajar mengajar (Syafi'I et al., 2020:141-142). Beragam aplikasi media social sudah tersedia dengan penetrasi internet yang begitu masif. Menurut Kadir dan Hidayat (2019:5) media sosial memiliki manfaat dalam menujang pendidikan anak.

Pada tahap ini, Tim PKM melakukan kunjungan pendahuluan kepada pengelola TK Al-Zharufa. Setelah menyampaikan maksud dan tujuan, akhirnya pihak pengelola sangat mengapresiasi dan menyampaikan kesediannya untuk melakukan kerjasama dalam kegiatan pelatihan. Hanya saja, berdasarkan pertimbangan situasi dan kondisi pandemic Covid-19, pelatihan hanya dilaksanakan 1 (satu) hari dengan model pembelajaran daring.

Setelah disepekati bersama, akhirnya tersusun jadwal kegiatan penyuluhan seperti pada tabel berikut. 


\begin{tabular}{|c|c|c|c|}
\hline \multicolumn{3}{|c|}{$\begin{array}{l}\text { ABDI WIRALODRA } \\
\text { JURNAL PENGABDIAN KEPADA MASYARAKAT }\end{array}$} & $\begin{array}{l}\text { ISSN 2656-5501 (Print) } \\
\text { ISSN 2714-8041 (Online) }\end{array}$ \\
\hline \multicolumn{4}{|c|}{ Tabel 1. Jadwal Kegiatan Sosialisasi } \\
\hline No. & Waktu & Materi Sosialisasi & Pemateri \\
\hline 1 & $08.00-08.30$ & $\begin{array}{l}\text { Pembukaan dan Pengarahan } \\
\text { Teknis Kegiatan }\end{array}$ & $\begin{array}{l}\text { Pihak Sekolah/ } \\
\text { TK/Tim PKM }\end{array}$ \\
\hline 2 & $08.30-10.00$ & $\begin{array}{l}\text { Model Pembelajaran Daring } \\
\text { TK }\end{array}$ & Livia Astuti \\
\hline 3 & $10.00-12.00$ & $\begin{array}{l}\text { Pemanfaatan Aplikasi Media } \\
\text { Sosial dalam Pembelajaran } \\
\text { Daring TK }\end{array}$ & Desty Rara Pringgandinie \\
\hline 4 & $12.00-13.00$ & Istirahat & - \\
\hline 5 & $13.00-14.30$ & $\begin{array}{l}\text { Etika Bahasa dalam } \\
\text { Penyampaian Informasi } \\
\text { Pembelajaran Daring TK }\end{array}$ & Deni Hadiansah \\
\hline 6 & $14.30-16.00$ & $\begin{array}{l}\text { Penguatan Kerjasama } \\
\text { Sekolah dan Orangtua dalam } \\
\text { Pembelajaran Daring }\end{array}$ & $\begin{array}{l}\text { - Fajar Setyaning Dwi } \\
\text { Putra } \\
\text { - Anne Rahaju }\end{array}$ \\
\hline 7 & $16.00-$ & Isian Survey/Tutup & \\
\hline
\end{tabular}

Berdasarkan rencana jadwal yang telah disusun, kegiatan pelatihan telah dilaksanakan secara lancer secara virtual menggunakan aplikasi Zoom. Adapun infromasi-informasi teknis sebelum dan sesudah pelaksanaan, digunakan pula aplikasi WhatsApp. Kemudian pada sesi isian survey, Tim PKM mengunakan tautan GoogleForm yang disebar baik pada chat Zoom maupun WhatsApp. Intinya kegiatan pelatihan direncanakan secara matang dan dikoordinasikan dengan baik antara Tim PKM dengan pengelola sekolah/TK Al-Zharufa.

\section{Tahap Pelaksanaan Sosialisasi}

Pada pelaksanaannya, tentu saja disesuaikan dengan jadwal yang telah disusun dan disepakati. Beberapa materi sosialisasi tentu saja disesuakan dengan kenutuhan guru-guru TK Al-Zharufa dan kemampuan penyuluh (Tim PKM). Secara umum, materi berkaitan dengan pemanfaatan aplikasi media sosial dalam pembelajaran daring di TK.

Kegiatan sosialisasi dilaksanakan selama 1 (satu) hari secara daring atau memanfaatkan kelas virtual melalui aplikasi Zoom Meeting, pada hari Senin, 14 September 2020. 


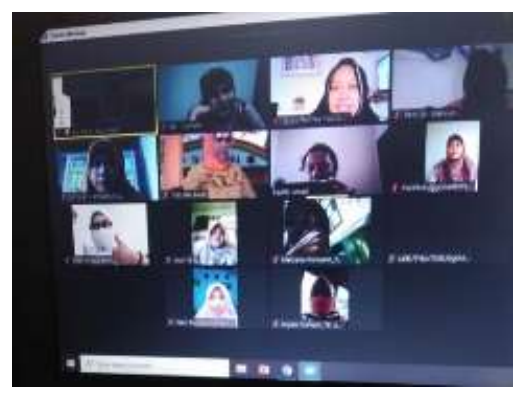

Gambar 6. Screenshot Sosialisasi Vitual TK Al-Zharufa

Pada Gambar 6. terlihat bahwa pelaksanaan kegiatan sosialisasi dilaksanakan secara virtual dan secara umum berjalan lancar. Secara teknis, tidak mengalami kendala seperti listrik mati, jaringan internet lemah, ataupun kendalkendala lain. Hanya saja, pada awal acara, beberapa peserta ada yang telat masuk ke kelas virtual, hal ini dikarenakan perangkat yang digunakan peserta sosialisasi tidak sama. Beberapa peserta ada yang menggunakan perangkat HP, sisanya menggunakan PC (Leptop).

Kemudian perlu disampaikan, selama sosialisasi tercipta diskusi yang aktif antara peserta dengan pemateri. Bahkan bisa dikatakan, pemateri mendapat informasi banyak dari peserta berkaitan dengan problematika dan dinamika pembelajaran daring selama pandemi Covid-19. Simpulnya, guru-guru TK AlZharufa dapat mengikuti kegiatan sosialisasi dengan baik dan aktif.

\section{Tahap Evaluasi Kegiatan Sosialisasi}

Pada tahap ini, pada dasarnya evaluasi secara umum melalui survey mini peserta terhadap keterlaksanaan penyelenggaraan kegiatan. Survey dilaksanakan melalui tautan GoogleForm yang terdiri dari 5 (tiga) pertanyaan utama, meliputi: (1) Apakah sekolah memfasilitasi kegiatan pembelajaran darinmg?; (2) Media apa yang digunakan dalam pembelajaran daring?; (3) Apakah kegiatan sosialisasi menambah wawasan tentang pembelajaran daring?; (4) Apakah materi sosialisasi menarik?; dan (5) Apakah perlu dilaksanakan sosialisasi lanjutan? 


\section{ABDI WIRALODRA}

JURNAL PENGABDIAN KEPADA MASYARAKAT
ISSN 2656-5501 (Print)

ISSN 2714-8041 (Online)

Survey dilaksanakan kepada pengelola TK Al-Zharufa yang mengikuti pelatihan sebanyak 9 orang. Berikut hasil evaluasi kegiatan sosialisasi berdasarkan survey mini yang dilakukan Tim PKM.

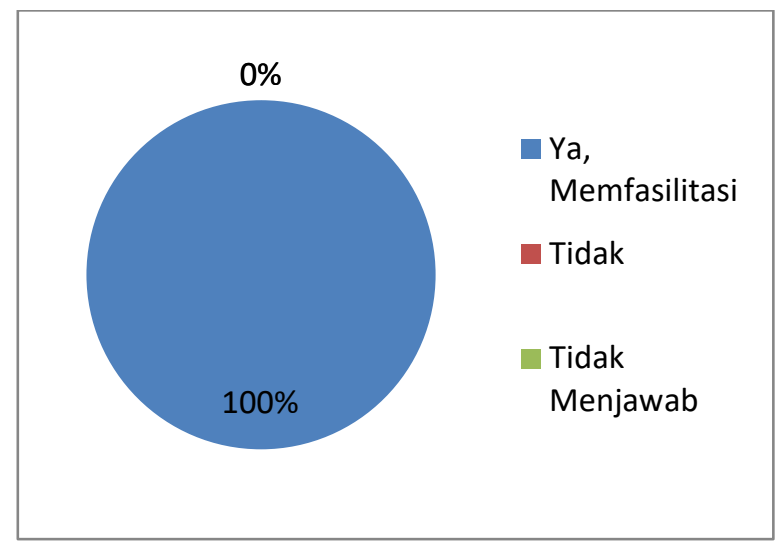

Grafik 1. Dukungan Sekolah

Berdasarkan Grafik 1., dapat dijelaskan bahwa pada pertanyaan (1) apakah pihak sekolah memfasilitasi dan mendukung pembelajaran daring, seluruh peserta (100\%) menjawab (Ya, memfasilitasi). Adapun pada survey pertanyaan (2) media apa yang digunakan oleh guru selama melaksanakan pembelajaran daring, hasilnya sebagai berikut.

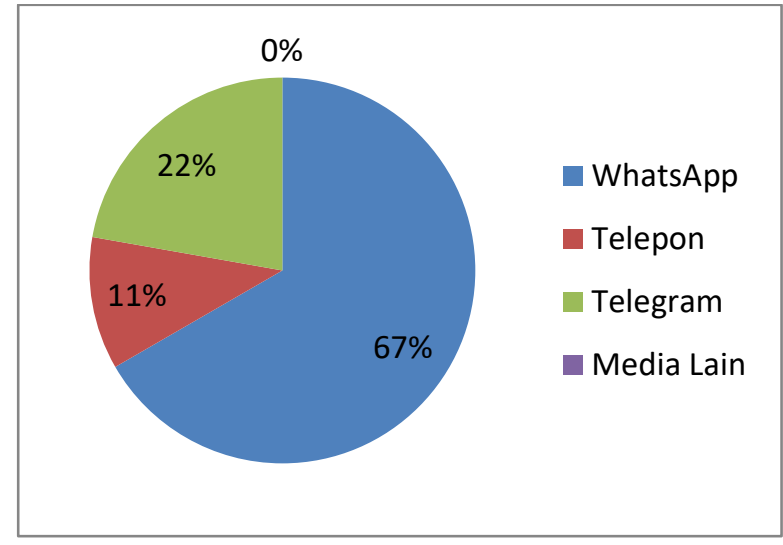

Grafik 2. Media Pembelajaran Daring 


\section{ABDI WIRALODRA}

JURNAL PENGABDIAN KEPADA MASYARAKAT
ISSN 2656-5501 (Print)

ISSN 2714-8041 (Online)

Berdasarkan Grafik 2., dapat dijelaskan bahwa di TK Al-Zharufa guru mayoritas menggunakan aplikasi media sosial WhatsApp dalam kegiatan pembelajaran daring (67\%). Sisinya menggunakan telepon (11\%) dan Telegram $(22 \%)$. Berdasarkan hasil survey, tidak ada guru yang menggunakan media lain.

Kemudian berdasarkan pertanyaan yang berkaitan langsung dengan kegiatan sosialisasi, meliputi (1) Apakah kegiatan sosialisasi menambah wawasan tentang pembelajaran daring, apakah materi pelatihan menarik, dan apakah perlu dilaksanakan sosialisasi lanjutan, hasil survey tergambar sebagai berikut.

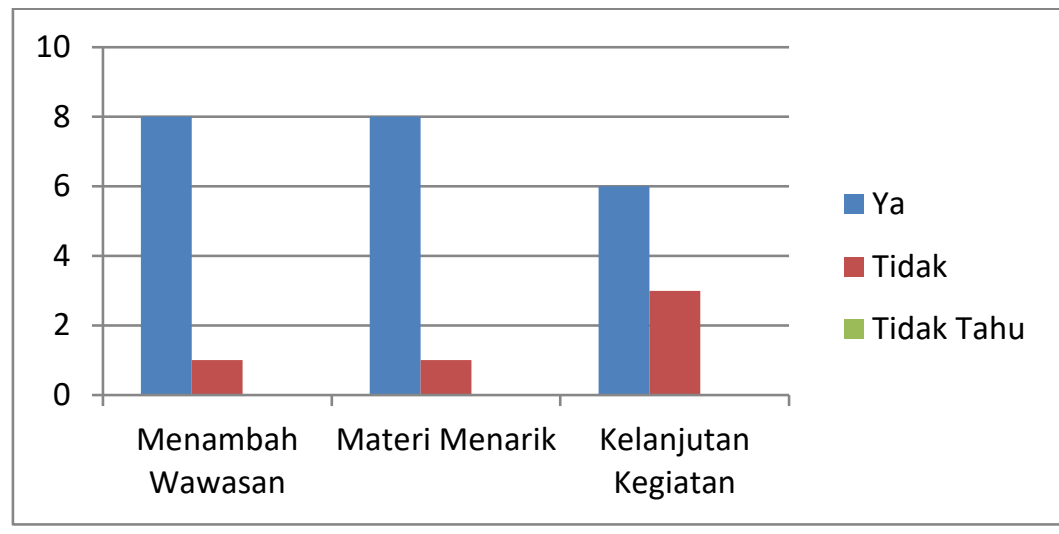

Grafik 3. Pernyataan Peserta Pelatihan

Berdasarkan Grafik 3., dapat dijelaskan bahwa mayoritas peserta merasa kegiatan sosialisasi telah menambah wawasan. Selain itu, terungkap bahwa kegiatan sosialisasi yang dilaksanakan materinya menarik. Hal ini bisa jadi akibat topik pembelajaran daring sedang actual di tengah pandemic Covid-19 melanda negara Indonesia yang berpengaruh terhadap dunia pendidikan. Adapun pada pertanyaan terakahir, terdapat 3 (tiga) peserta yang menyatakan bahwa kegiatan sosialisasi tidak perlu dilanjutkan dengan alasan bahwa perlu dibuat dulu program Learning Management System (LMS) tingkat sekolah yang lebih baik. Setelah LMS dirasa siap, selanjutnya dapat dilaksanakan kembali pelatihan. 
Berdasarkan paparan di atas, jelas bahwa selama kebijakan pembelajaran daring pada jenjang TK dilaksanakan, seyogyanya guru-guru perlu diberi pelatihan untuk menambah wawasan baik secara teoretis maupun praktis. Beberapa pelatihan yang sifatnya teknis penggunaan aplikasi pembelajaran sederhana, seperti penggunaan GoogleClasroom, Zoom Meeting, GoogleMeet, dan aplikasi lainnya perlu dilaksanakan. Pada kondisi demikian, memang kolaborasi antara pihak pemerintah dengan sekolah, pihak sekolah dengan orang tua, dan guru dengan siswa perlu dioptimalkan. Harapannya, agar kegiatan pembelajaran daring selama menghadapi pandemi Covid-19 dapat berjalan lancar dan tetap memenuhi azas pendidikan bermutu.

Demikian, apabila guru-guru pada $\mathrm{Tk}$ Al-Zharufa kelak dapat memanfaatkan secara optimal berbagai media sosial yang tersedia, maka pembelajaran daring akan lebih efektif dan menyenangkan. Hal ini sejalan dengan hasil kajian Palupi (2020) bahwa media sosial seperti Youtube dapat dimanfaatkan dalam pembelajaran anak usia dini. Artinya bahwa media sosial jika dimanfaatkan dengan optimal, dapat meningkatkan daya kecerdasan intelektual, emosional, spiritual, dan sosial pada anak usia dini. Pada sisi lain, penggunaan media sosial bagi anak usia dini tentu saja harus di bawah pengawasan dan pembimbingan oleh guru maupun orang tua secara ketat.

\section{Kesimpulan dan Saran}

Kegiatan penyuluhan yang dilaksanakan di TK Al-Zharufa meliputi beberapa tahapan, yaitu: (1) Tahap perencanaan dan pengorganisasian, (2) Tahap pelaksanaan pelatihan, dan (3) Tahap evaluasi kegiatan pelatihan. Seluruh tahapan dapat terlaksana dengan baik dan lancar. Secara umum, dapat disimpulkan bahwa pada dasarnya guru-guru di lapangan, khususnya pada TK Al-Zharufa sangat memerlukan kegiatan penyuluhan untuk mengembangkan wawasannya baik secara teoretis maupun praktis tentang pelaksanaan pembelajaran daring selama pandemi Covid-19. Demikian, kegiatan penyuluhan dalam upaya menambah wawasan 
kepada guru-guru TK tentang pembelajaran daring selama pandemi Covid-19 perlu dilaksanakan secara berkala dan berkelanjutan.

\section{E. Ucapan Terima Kasih}

Ucapan terima kasih kami sampaikan kepada sivitas akademika FKIP Universitas Insan Cendekia Mandiri Bandung, Ketua Yayasan, Kepala Sekolah, dan Guru-Guru TK Al-Zharufa Kota Cimahi yang telah memfasilitasi kegiatan PKM. Semoga ke depan dapat diselenggarakan berbagai kerjasama kegiatan yang lebih aktual dan optimal.

\section{Daftar Pustaka}

Adhe, K. R. (2018). Model Pembelajaran Daring Mata kuliah Kajian PAUD di Jurusan PG PAUD Fakultas Ilmu Pendidikan Universitas Negeri Surabaya. Journal of Early Childhood Care \& Education, 1(1), 26-32.

Adiwijaya. (2020). Kesenjangan akses internet di Asia Tenggara jadi tantangan bagi pengajaran online akibat pandemi COVID-19. Detik. Net.

Ayuni, Despa et al. (2021). "Kesiapan Guru TK Menghadapi Pembelajaran Daring Masa Pandemi Covid-19”, dalam jurnal Pendidikan Anak Usia Dini, Vol. 5 Issue 1 (2021), hlm. 414-421, tersedia di file:///C:/Users/ZET.COM/AppData/Local/Temp/579-3189-1-PB.pdf

Ban, AW Van Den dan HS. Hawkins. (1999). Penyuluhan Pertanian. Kanisius. Yogyakarta. BAPPEDA.

Bredekamp, Sue \& Copple, Carol. (1997). Developmentally Appropriate Practice in Early Childhood Programs. Washington: NAEYC.

Eko Suhendro \& Syaefudin. (2020). Nilai-Nilai Kemanusian dalam Pendidikan Anak Usia Dini Inklusi. JEA (Jurnal Edukasi AUD), 6(1), 1-12. https://doi.org/10.18592/jea.v6i1.3430

Hasbi, Muhammad, RR. Lestari K. Wardhani dan Elis Widiyawati. (2020). Bermain Bahasa di Rumah dalam Melaksanakan Belajar Dari Rumah. Jakarta: Direktorat PAUD Kemendikbud.

https://mediaindonesia.com/humaniora/351919/ini-manfaat-belajar-daring-untukanak-tk-dan-paud

Kadir, Abdul dan Arif Hidayat. (2019). "Peran Orangtua dalam Pemanfaatan Media Sosial Terhadap Pendidikan Anak", dalam Prosiding Seminar Nasional Pendidikan dan Call for Papers (SNDIK) I 2019, tersedia di https://publikasiilmiah.ums.ac.id/bitstream/handle/11617/11172/1.pdf?sequen $\mathrm{ce}=1$ \&isAllowed $=\mathrm{y}$

Mansur. (2011). Pendidikan Anak Usia Dini dalam Islam. Yogyakarta: Pustaka Pelajar. 
Oktaria, R., \& Putra, P. (2020). Pendidikan Anak dalam Keluarga sebagai Strategi Pendidikan Anak Usia Dini saat Pandemi Covid-19. Jurnal Ilmiah PESONA PAUD, 7(1), 41-51.

Palupi, Intan Diyah Retno. (2020). "Pengaruh Media Sosial pada Perkembangan Kecerdasan Anak Usia Dini”, dalam Jurnal Edukasi Nonformal, Vo. 1 No. 2, $\mathrm{HIm}$. 127-134, tersedia file:///C:/Users/ZET.COM/AppData/Local/Temp/426-Article\%20Text-887-110-20200425.pdf.

Roza, D., Nurhafizah, N., \& Yaswinda, Y. (2019). "Urgensi Profesionalisme Guru Pendidikan Anak Usia Dini dalam Penyelenggaraan Perlindungan Anak", dalam jurnal Obsesi: Jurnal Pendidikan Anak Usia Dini, 4(1), 277. https://doi.org/10.31004/obsesi.v4i1.325

Runisah, R., Ismunandar, D., Gunadi, F., \& Nurafifah, L. (2019). Pelatihan Penggunaan Geogebra Sebagai Upaya untuk Meningkatkan Profesionalisme Guru SMP/MTs di Kecamatan Sindang Indramayu. Abdi Wiralodra : Jurnal Pengabdian Kepada Masyarakat, $\quad$ 1(2), 67-79. https://doi.org/10.31943/abdi.v1i2.12.

Semiawan, Conny. (2002). Belajar dan Pembelajaran dalam Taraf Usia Dini: Pendidikan Prasekolah dan Dasar. Jakarta: Prenhalindo.

Setiana, L. (2005). Teknik Penyuluhan dan Pemberdayaan Masyarakat. Yogyakarta: Penerbit Andi.

Suhenro, Eko. (2020). "Strategi Pembelajaran Pendidikan Anak Usia Dini di Masa Pandemi Covid-19", dalam GOLDEN AGE: Jurnal Ilmiah Tumbuh Kembang Anak Usia, Vol. 5 (3), September 2020, hlm. 133-140, DOI:https://doi.org/10.14421/jga.2020.53-05.

Syafi'i, Imam et al. (2020). "Penerapan Video Pembelajaran Daring Anak Usia Dini pada Masa Pandemi Covid-19", dalam jurnal Al-Athfaal: Jurnal Ilmiah Pendidikan Anak Usia Dini, Vol.3 No. 2 (2020), hlm.140-160, tersedia di http://ejournal.radenintan.ac.id/index.php/al-athfaal

UU Nomor 14 Tahun 2005 tentang Guru dan Dosen

Wiyani, Novan Ardy. (2014). Psikologi Perkembangan anak Usia Dini. Yogyakarta: Gava Media.

Zamzami, E. M. (2021). Aplikasi Edutainment Pendukung Pembelajaran Jarak Jauh TK Merujuk Standar Nasional PAUD. Jurnal Obsesi : Jurnal Pendidikan Anak Usia Dini, 5(2), 985-995. https://doi.org/10.31004/obsesi.v5i2.750

Zubaidi, M. (2020). "Hubungan Profesionalisme Pendidik Pendidikan Anak Usia Dini dengan Efektivitas Pembelajaran PAUD di Kota Gorontalo," dalam Jurnal Obsesi: Jurnal Pendidikan Anak Usia Dini(Vol. 4, Issue 2, p. 1060). https://doi.org/10.31004/obsesi.v4i2.505. 